\title{
Review on Importance of FTC in Adoption of New Farm Technology In Ethiopia
}

\author{
HAILE TAMIRU URGESSA \\ Bule Hora University, College of Agricultural Science, Department of Agricultural Economics \\ P. O. Box 144, Bule Hora, Ethiopia
}

\begin{abstract}
Though farmers training center is a important in adoption of new farm technology and improving incomes of farmers through improving agricultural productivity .Even though different FTC have been established in different part of the country, the effectiveness is still low. Provision of training through this center is to important in adoption of new farm technologies to the agricultural and other sub-sector in Ethiopia, but rate of adoption and dissemination of the technology is found to be very minimal. However, there is a wide gap exists between productivity at different farmers training center and farmers' field. To fill this gap, training is an important tool. The findings of study indicate that the major area of training needs adoption of new farm technology. Another gap identified in this review, even though, in improving income of the farmers through improving agricultural productivity and adoption of new farm technology, however, few and no recent research have been done on farmers training center in different part of Ethiopia. Thus, this review was sought to ascertain importance of farmers training in adoption of new farm technology and put highlight policy implication for further implementation of modern farm technology.
\end{abstract}

Keywords: Importance, farmers training center, Adoption, Technology

DOI: $10.7176 / \mathrm{JESD} / 11-7-02$

Publication date: April $30^{\text {th }} 2020$

\section{Introduction}

\subsection{Back ground of the study}

In the development of one country's agriculture is the most important sector and the most predominant activity of human kind (Fisseha, 2009). Majority of the world countries lead their life by different agricultural activity. In Ethiopia about $85 \%$ of the total population of the country led by agricultural activities and majority of these populations engaged under this sector (Aynalem, 2006). Even though agriculture has largest share of GDP and national export, its productivity is not sufficient to well-being the life of the people (Berhanu, Hoekstra and Tegegne, 2006). So the government of the Ethiopia develop different policy and strategy to improve agricultural productivity.

Agricultural Development Led Industrialization (ADLI) strategy has been adopted by the government of Ethiopia based on which, the resources necessary for the development of the industry and other growth sectors of the country can be obtained when agricultural productivity reliably grow. The government is implementing a development strategy with the objective of altering the outdated farm practices of the majority of rural farmers and improves their living standards by increasing farm productivity as well as to bring a sustainable economic development in the country $(\mathrm{MEDaC}, 1999)$. For the implementation of the development strategy is the establishment of agricultural technical and vocational training colleges which trains the developmental agents and provide their skills \& professions to work closely with farmers.

One of the basic reasons for low productivity of agricultural output is the lack of training, low skill, lack of new farm technology as well as lack of Know-how skill to adopt this new farm technology. Due to these factors the government implements and expanded farmers training center to improve the farmers' perception to adopt different farm technology in different rural areas. According to (Muluken and Maria , 2017) Farmers Training Centers is important to give training for farmers not only to improve their productivity but also to improve Knowhow skill in adoption to new farm technology. Since lack of technological adoption is another factor that influences agricultural productivity, most of the farmers are unable to adopt with new technology and they may apply back ward technology (Sharma and Gupta, 2011). Education of the farmers also can be another factor in adaptation of new farm technology; the literate and illiterate farmers are not equal on the application of the farm technology. And the rigidity of the farmer the conducive weather condition, accessibility of farm equipment, material s, transportation infrastructure and others may the factor for adoption of new farm technology (Nigatu, 2010)

Technology can be reached farmers through technology transfer. Technology transfer refers to the general process of moving information and skills from information or knowledge 'generators' such as research laboratories and universities to clients such as farmers'. The outcome of new technology transfer is the farmers' adoption and bringing this into practice and further diffusion to other individuals in the community (Ngoc Chi and Yamada, 2002).

This development strategy is the establishment and organization of farmers' training centers to provide 
training to farmers by the professionals those graduates from the colleges. The main reason for establishing farmers training centers is to produce skilled farmers that can transform the country's agricultural production from subsistence to market oriented production system, bring a sustainable economic growth by raising the sector's output and productivity and effectively use the natural resources of the country (Nigatu, 2010).

There is no designed plan how to improve FTCs functions that are capable to create a variation to productivity, success and sustainability in smallholder agriculture. Then, regular strategic valuation and learning to make continuous improvement will be needed for human resource progress for agricultural commercialization and rural alteration, predominantly to improve the awareness, abilities and perception of producers through FTCs. Therefore, to make appropriate, sensitive, concrete and impact-oriented FTCs, any agricultural improvement actions that the government has to introduce must be significantly. According to the suggestion (MoA, 2000), the goal of every farmer training centers is to make farmers, who are commercial oriented, ecologically conscious, can create use of up-to-date technologies and produce quality farm products.

The study focused that a wide gap exists between productivity at different farmers training center and farmers' field. To fill this gap, training is an important tool. The findings of study indicate that the major areas of training needs adoption of new farm technology [21]

Another gap identified in this review, even though, in improving income of the farmers through improving agricultural productivity and adoption of new farm technology, however, few and no recent research have been done on farmers training center in different part of Ethiopia. Due to this fact, in view of the above statements the review is interested to focus the farmers training center in Ethiopia. Therefore, the objectives of this review paper are:

To review the importance and challenges of farmers' training center (FTC)

To highlight policy implication to focus on further implementation of Farmers training center

\section{Farmers' Training Centers (FTC) in Ethiopia}

\subsection{Conceptual frame work of Farmers' Training Center (FTC)}

According to (Tesfaye, Ermias and Dirk, 2010) In Ethiopia, where public agricultural extension remains dominant in service provision is fair developing; strengthening community agricultural extension has received due strategy attention. Thousands of farmer training centers (FTCs) have been established by government with considerable contributions from rural communities. The Ministry of Agriculture (MoA, 2002 )planned to establish at least 15,000 FTCs, one in every rural kebele. About 8, 500 FTCs have been built so far and about 45,000 DAs are engaged as service providers in these FTCs.

Wuletaw(2014) stated that, farmers are further probable to adopt innovations and become more productive with the help of basic education and extension services. In rural areas, particularly poor farmers, access to education is still much lower and the quality of non-formal education is poorer and frequently irrelevant to their lives. Numerous trainings, particularly modular and other non-modular trainings have been given to farmers in rural communities.

(Tsion Ranjan and Teklu , 2010) Have explained that, Farmer training centers (FTCs) have been planned and used to improve agricultural extension amenities provision in various developing countries. Ethiopia is encouraging the FTC approach with the expectation of improving the extent and effectiveness of agricultural extension and the participation of farmers in technology development. Within the broader strategy of agricultural development-led industrialization (ADLI), it is intended that FTCs will contribute to overall rural alteration in Ethiopia that would not be restricted to agricultural development. Extension amenities extending from ability improvement on use of enhanced farming technologies (e.g. improved seed production systems, improved agronomic practices, integrated pest management, animal husbandry and agroforestry, etc.) and providing marketoriented information and communication and advisory services, to name a few, would be provided through the FTC approach (Nigatu, 2010).

In addition to providing information, improving communication and ability development activities, the agricultural extension services at the FTCs will support in connecting farmers with institutional provision services such as input supply, credit, cooperative promotion and development offices and marketing services (Njine, 2014).

According to [10] view, Field-extension service is a strong foundation of FTCs and in several circumstances, trained extension agents are already in place and nearby to farmers. So far, thousands of FTCs have been established throughout Ethiopia and tens of thousands of extension agents have been trained to support farmers to increase their practices (Tigist ,Kavitha, Nachimuthu, Haimanot and Mohammed, 2017). This indicates that various farmer associations (PAs), districts and regional offices are well organized with professionals who are trained to address new challenges in agriculture and some studies suggest that pockets of entrepreneurialism and innovations are developing in specific FTCs and districts of the country due to the new approach to extension (MOARD, 2009).

However, although there are rare circumstances where intentional objectives are attained, the majority of the FTCs are not rendering the essential extension services to rural communities. Various FTCs have not been 
completely equipped, staffed and/or budgeted for as originally planned. There also appears to be significant variation in their operations across the country.

Numerous limitations are observed within the field-level extension system and need specific consideration. These include abundant staff turnover, shortage of basic infrastructure, facilities (such as equipment and demonstration sites) and resources (including staff and financial). Most FTCs do not have basic inputs for carrying out typical extension activities on the demonstration sites[10]. In some circumstances, FTC locations are used as storage for crops and other materials or serve as a source of income for the PA administration instead of as a 'centre of participatory extension delivery' as intended (Tigist ,Kavitha, Nachimuthu, Haimanot and Mohammed, 2017).

Moreover, there are grievances about the capacity of the development agents to assist farmers due to shortage of practical skills and apparatuses to efficiently implement the FTC center extension strategy. In addition, the FTCs and community extension in universal do not have suitable mechanisms for accessing current agricultural knowledge and information. In general, although FTCs are important resources and provide opportunities to move participatory extension forward, making them more functional and effective remains a challenge, despite the fact that FTCs can reach many farmers at a minimal cost (Njine, 2014).

The Livestock and Irrigation Value Chains for Ethiopian Smallholders (LIVES) project is using FTCs in some intervention areas to demonstrate new technology for fodder development and irrigated vegetable crops interventions. LIVES plans to collaborate with agricultural offices such as the bureau of agriculture, the livestock development and health agency and the irrigation development agency, PA administration and other stakeholders to boost the role of FTCs in intervention areas. A comprehensive strategy is, however, needed to revitalize the use of FTCs as centers for effective technology demonstration and spaces for participatory learning (Zewdie,Gemeda,Abule and Amenti, 2015).

\subsection{Importance of FTC in Ethiopia}

According to Tsion Ranjan and Teklu ( 2010) suggestion, Farmers training center is important mechanism in order create and develop knowledge and attitude of farmers in areas of adoption of new farm technology. And the scholars define the attitude is the degree of positive or negative feeling associate with good, technology or people or farmers are ideal or idea in which they are different and also describe the farmers training center was intended to bring about desirable change in behavioral dimension of farmers. So from this scholars idea farmers training center is important to create whether positive and negative attitude in adoption of new farm technology (Mwangi S. Kimenyi, Temesgen . Deressa, Jessica Pugliese, 2014).

Training farmers or education for development is one of the several actions that necessity to be carried out by development organizations. Though the important role played by farmers in providing agricultural products is well understood by the developing countries, the problem of food self-sufficiency is still a great challenge to many of them. To resolve such problems, some of the activities carried out by the developing countries are provision of agricultural inputs and training, especially transferring technological information to the farmers (Terrefe, 1992).

Extension is an instrument that introduces improved cultural practices and new technologies to farmers after technology generation by research center. The contribution of extension service in dissemination of information and technologies may be influenced by a number of factors such as extension approach, policy, budget, infrastructure, extension program planning, extension monitoring and evaluation. Besides commitment of rural Extension Workers to work with farmers, number of contact, coverage and participation of farmers in extension program have significant role for technology dissemination (Alemayehu, 2008).

The FTC provides new and ambitious farmers with hands-on, practical training that they will need to own and manage a varied vegetable farm. It enables participants to learn a variety of skills that are critical to new farmer success. The center have been working on training program developments; and over the next year look forward to offering new, more accessible training opportunities for farmers, gardeners, and community members with varying levels of experience. The FTC partners with other organizations to deliver a wide variety of training opportunities, including formal courses through Cooperative Extension and workshops with developmental Agents Link and the Peasant Association for Sustainable Agriculture. In this way, our site serves as a living classroom, providing opportunities for demonstration and experiential agricultural training for the community [13].

The purpose of the Farmer Training center is to support and serve prospective, beginning and experienced farmers through training in business planning, financial management and regenerative agricultural practices. Our commitment is to work with those who wish to become sustainable and organic agriculture farmers or growers for our local food system. We also promote the development of farmer-to-farmer training programs, both locally and nationally. Our standards of performance are measured by the number of farmers we help successfully enter or transition into sustainable agriculture production, as well as the linkages we make in the areas of land acquisition $[11]$

\subsubsection{Farmers training center in improving Income of household}

According to Waddington et al. (2010) view FTC establishment document, is targeted to provide training and the 
training enables farmers' to use modern farm technology to increase household income. This is intended to be achieved by providing technical information and advice, training, and demonstration related to crop, livestock, and natural resources, with crop and livestock being the most important components where FTCs are actively engaged in currently. However, according to [8] suggestion restricted the concept to the dominant agricultural sectors of the investigated area, crop and livestock activities. Aggregating these two sources of income; operationalize farm income as the total value of income from crop and livestock production net of the cost of intermediate inputs associated with them.

\section{Income from Crop Production}

Yield income by household is calculated as the value of yield traded, used for individual consumption and deposited, including the value of yield residues net of the intermediate inputs related with crop production (Cunguara and Darnhofer, 2011). The stated amount of production sold by product is changed in terms of Birr. According to the survey gathered, (Muluken and Maria , 2017), the total income generated from crop production US\$1 = 18.7193 Birr and $€ 1=24.8302 "$ Birr.

Totally, the revenues from each yield type sold, the achieved the total gross income realized by each household from yields sold. The obtained the amount of each household's individual consumption and yield stored for future consumption or sale. Moreover, the collected details on household expenses related to intermediate inputs for crop production fertilizer, pesticides, seeds and seedlings, transport, and other items (Todo, Yasuyuki and Ryo, 2013). According to Muluken and Maria (2017) suggestion, a significant average gain of annual farm income by participants of the training, ranging from Birr 9557 to Birr 10,388 per household

FTC-based modular training packages can show progressive roles in affecting rural people's livelihoods in Ethiopia. Although it has been shown currenttly that the common FTCs in the country have positive contributions towards decreasing headcount poverty and increasing consumption growth (Tassew, 2009), such analysis considers neither on-farm training nor FTC-based provision of training. In this article, the result show the positive effects of FTC-based training on farm and crop income (Tesfaye and Sehai, 2011).

In particular, Samuel, (2011)show an increase of 37-95\% (direct participants) and 27-55\% (indirect participants) per capita gross agricultural revenues between 2004 and 2007. In general, in this article we show that FTC-based training has a positive and significant impact on household's farm income, which is reasonably robust to changes in matching methods.

\section{Income from Livestock Production}

Income from livestock production by household is calculated as the value of livestock products traded and charge from oxen gained net of the cost of intermediate inputs related with livestock production at household level (Davis.et.al, 2012). The respondents directly delivered information in value terms. As in the situation of crops, livestock products have been examined asking each respondent to deliver particulars on each product sold in the last 12 months preceding the survey (Benin et al. 2012). The respondents also delivered particulars on intermediate cost incurred in livestock production, among which are expenditures for forage, water, and veterinary services. These have been aggregated and deducted from gross livestock income to calculate livestock income. Having calculated crop and livestock incomes separately derived agricultural (farm) income by combining both crop and livestock. Also

\subsection{Some challenging factor for effective performance of FTCs}

There are several factors for effective implementation of farmers' training center. Some of the problem occurred due to Social constraint such as Low community participation, Drop out ,Expectation of benefit ,Lack of educated farmers and Lack of demonstration area .And the other problem is Institutional constraint Lack of commitment, Lack of teaching material, Lack of transportation, Lack of guideline and curriculum modules[11]. Extension is a learning procedure for bringing about the maximum amount of required variations between the individuals which comprises both education and training and necessities certain implements or systems usually known as extension training approaches [1].

There are large numbers of FTC constructed in in different part of the Ethiopia. However, they have achieved to contribute with their various problems, which are mostly originated from inappropriate planning, resource distribution and organization. In linking with the difficulties of the FTCs, the study conducted by (Millennium Challenge Corporation, 2012), indicate that creating FTCs efficient, reactive and dynamic remains the challenge. Moreover, statistics produced from observation and focus group discussion with concerned stakeholder and clients, this study supports the facts, indicating that FTCs in the areas studied have suffered from human resources shortage, absence of demonstration sites, absences of the materials and improper positioning to reach the needy smallholder farmers, who have starved of right and timely information and demand derived and affordable agricultural technologies (Fanos, 2015).

Education is the procedure by which a specific, through his own action, achieves an alteration in his performance. It is a dynamic procedure on the part of the learner. On other hand there were numerous issues affecting effective performance of FTC such as:- 


\subsubsection{Administrative competences within the service}

One of the fundamental impeding forces to effective growth is shortage of effective communication within and among different performers (Samson, 2007). Communication in extension association takes place within the organization and outside the association between different performers in order to attain administrative objectives. Universal, communication in a reputable Institution includes both official and informal communication. Official communication emphases on work related communication requisite by the association, and follows the recognized hierarchical structure, while informal communication emphases on sustaining group members' community necessities (Rogers, 1988).

Extension administrations in developing countries face the major problems of expert ineffectiveness and shortage of inspiration among their workers. Further, several of the agricultural extension units of these countries do not have a precise coordination of human resource management. Appropriate preparation and controlling of human resources within extension administration is important to increase the competences, inspiration, and overall effectiveness of extension personnel. (Swanson, Bentz and Safranko, 1997)

Organization need to produce a small association to support a training program. The organizations require numerous features to perform effectively, that are clear authority, sufficient resource, agreed aims and good leadership. One of the most potential weaknesses of an extension service is the lack of vertical communication between workers in the field and their chiefs at regional and national headquarters and vice versa. Supervision of field staff is often erratic, or may be almost non-existent or poor ( Rogers and Svenning, 1969).

An efficient extension organization needs to develop the capability of responding to changes in relation to its environment. Extension organizations have to cope with changes within and outside the organization, such as changes in farm technology

2.3.2. Capacity and numbers of trainers Insufficient amounts and qualifications of staff remain a challenging problem for community sector extension governments. Salaries and benefits are seldom competitive with those of similar private and community enterprises, resulting in low morale and high staffs turn over. Education levels may be quite low, especially for farmer contact staff. The ability to attract and retain qualified extension staff is limited in most countries by civil service salary scales established by other agencies of government (Fanos, 2015).

The key actors in the teaching-learning procedure at FTCs are the extension agent's. The instructors at FTCs should be well knowledgeable and experienced enough with good personal qualities. On the significance of quality, several academics have stated their opinions at different times. Marshall, (1920) defined as that knowledge is our most powerful engine of production. Supporting the view, Roling, (1988) said that working through people as an extension communicator requires professional skill and insight which must be underpinned with knowledge. Spicer (1986) expressed that, changing peoples' customs is an even more delicate responsibility than surgery. (Esman and Milton , 1980) Noted that professionally qualified people, even when available, resist placement in rural areas; and when they are drafted into such assignments they often lineated from the majority of their rural publics and so ill-equipped to work in a resource poor situation.

\subsubsection{Sufficient training for extension staff}

The Rural extension employee is the only extension worker who teaches production recommendations to farmers. The duty of all other extension worker is eventually to make the farmers more effective in his work. The rural extension worker should attend s short term training courses from time to time. These may comprise one or two day pre-seasonal and orientation workshops held by district staff on specific agricultural topics. As agriculture develops more particular and multifaceted, there is a frequent prerequisite for more highly trained and specialized extension workers (Bernor, Daniel and Baxter, 1984). Terrefe( 1992) also expressed his view on development agents as the development agents (DAs) are the link between the farmers and ministry of agriculture and rural development .That is about developmental Agents are the tangible front line field worker of Ministry of Agriculture and Rural Development at grass roots level.

There is a great attention whether we have actually the right individuals qualified as development agents who are well equipped with rudimentary practical/technical skills, extension/communication techniques.

(Terrefe, 1992) Also stated his opinion on development agents as the development agents (DAs) are the link between the farmers and ministry of agriculture and rural development. That is to say DAs are the sure front line field staff of Ministry of Agriculture at grass roots level. They link with the farmers and transfer any reaction to the staff of the ministry. However, there is a great anxiety whether we have actually the right people trained as development agents who are well equipped with basic technical skills and communication techniques. Considering the majority of the Developmental Agents, many believe that we do not have the right people for the challenging duty of supporting the farmer to pinpoint his/her own difficulties and find solutions for.

Ames (1989) stated that if the investment in trained man power is limited or lacking, information may never be utilized. With supporting this view, Schultz (1981) suggested that for developing highly productive economy only natural resources, physical capital and raw labor are inadequate. Dynamics development needs a extensive array of human skill.

Clark (1987) mentioned that the effectiveness of the educational programs of extension depends on the 
abilities of its professional and volunteer staff. Continued professional development must become a priority of extension is to remain a viable source of information for changing world.

\subsection{Need of Farmers training center (FTC) in Technological adoption.}

In this regard, Farmers Training Centers (FTCs), which have established with purpose to alter the extension service delivery from sole technology transfers models to human resource and social capital development approach have indispensible role in agricultural knowledge and information system for better production and productivity and also expected to contribute for rural development and tackling the problems of household food security (MoARD, 2009).

According to Berhanu, Hoekstra and Tegegne,( 2006), FTCs are also probable to support as centers for the transfer of improved technologies and knowledge, skill development, and the provision of other institutional support services. Agricultural knowledge and technology transfer of the method in the country instructions unidirectional, top-down method, in which the role of the indigenous knowledge and participatory planning based specific felt needs of the poor, are seldom taken into account (William. McBride and Daberkow, 2003). The technical aspects of extension experts, who are major planners, facilitators, promoters, demonstrators and managers of agricultural knowledge and technology transfer is in many cases is observed to be the challenging issues for agricultural extension in different Region.

The agricultural extension service functions from the background trust that improved agricultural productivity rely on mainly upon the recognition of enhanced traditional and technical alteration at the rural farm level and that peasant farmers can attain higher farm yields only if they adopt recommended scientific farming techniques in place of their traditional practices. But (Mahmud, Menale and Gunnar , 2009) have expressed the opinion that for peasant of different agricultural zones to adopt a new technology, they must be responsive of the technology, have valid and up-to-date information on the technology, the applicability of the technology to their farming system and receive the technical assistance necessary for the technology.

Truong and Yamada, (2002), have suggested that effective adoption of improved farming systems is predicated upon rural farmers gaining the essential knowledge and understanding of these technologies, a procedure most successfully accomplished by the agricultural extension service.

\subsubsection{Farmers training center FTC in Adoption of Modern beekeeping practice}

Ethiopia is a foremost in Africa in honey production. And it leading country in supply of beeswax production in the world (FAO, 2005).As it is known out-of-date beekeeping practice is the main and ancient type, implemented for more century in Ethiopia. It is characterized mostly by woodland beekeeping that is mutual in the forest covered in Ethiopia and place prepared for beekeeping which is practiced in the majority of the country (Nuru, 2007). This technique of beekeeping, particularly by hanging over the tree in the forest is not suitable for female farmers.

The other problems in out-of-date beehive is problem of low productivity with production per hive averaging "5-8kg/per colony/per annum" compared to modern beehives, which has average production of " $30 \mathrm{~kg} / \mathrm{per}$ colony/per annum" (MoARD,2007). By recognizing the possibility of apiculture subsector and the difficult related to out-of-date beehive, the government tried to introduce different beekeeping technologies to beekeepers. The establishment of beekeeping demonstration stations at different research center is too important. In 1960s to familiarize enhanced beekeeping technologies such as ,box hives, casting mold, honey extractor, honey presser, smoker, water sprayer, veil and glove introduced from other country to the beekeepers and to give beekeeping training for farmers and professionals can be stated ( (EBA, 2005).

Even though huge number of improved beehive technologies have been familiarized and encouraged by the regional bureau and other nongovernmental organizations over the past decade, however, the quantities of modern beehive technologies used by farmers were very restricted (Adesina, 2001). In addition, although tries have been made to improve the adoption and productivity of beekeeping by various organizations, some social, ecological and climatic factors were identified as constraints which hinder farmers from adopting the available beekeeping technologies (Degnet and Belay, 2001).

Longer farming experience implies accumulated farming knowledge and skill, which has contribution for adoption (Feder and Zilberman, 1985 ). According to Cramb(2003 ), confirmed that farmers' characteristics such as participation in field days and demonstration improve adoption of farm technology. Visiting beehive sites of other beekeepers or demonstration site help the beekeeper to develop his/her insight in bee-keeping. Farmer to farmer knowledge sharing visits also gives towards increasing positive awareness towards an improvement or a new technology (Malede and Degsew, 2013). Training is very significant to make understanding on the technology as well as to create the beneficiary more productive. Enamul and Saedah, (2009) stated that training might have instructed practical proficiency, more revelation to the subject substance and persuaded to adopt the improved technologies in the farms. Participation of beekeepers on demonstration and training of modern beehives were among the most significant determinants of adoption

\subsubsection{Farmers training center (FTC) in adoption of fertilizer application}

Fertilizer amplification and for raising farm productivity under increasing land restrictions and decreasing soil 
fertility. Fertilizer is one of the serious inputs used in improving smallholder food and agricultural productivity. Trends in fertilizer use are all the more worrying because without significant increases in the use of chemical fertilizers it will not be possible for the production of food and fiber to keep up with demand from a rapidly growing population (Kelly et al. 1998, )

According to (FOA.2002) the per capita food production in Ethiopia has shown downward trend. This was recognized to continuous sufficient unused periods resulting into infertile soils that essential to be replaced by fertilizers. Adanikin (2008), Asserted that under this situation the use of appropriate land improvement / intensification technology seems to offer an opportunity to substantially increase farm production and income levels. Traditionally, Ethiopian farmers have been using fertilizer primarily on export crops, but in recent years, an increasing quantity of fertilizers is being used on such food crops as rice, maize, wheat and teff. It has been discovered that there is inadequacy of the nutrient elements which is improve plant growth and development in the soil (Adesina and Baidu , 1995). Since then materials that will supply the inadequate nutrient elements have been produced technologically. Despite the effort of government to make these materials available for the farmers to use, the crop productivity is still not high.

The causes of these threat may be traced to the adoption patterns of the technology i.e. fertilizer which demands critical study in order to proffer lasting solutions. This study is necessary to be carried out because of the fact that there is increase in the production of fertilizer and crop yield is still not high. Therefore, it is glaring that high productivity innovation like fertilizer technology. It is pertinent to study some factors that determine the adoption pattern of this technology. Despite the alarming general trends and patterns, there is evidence of large differences among farmers in adoption and use of fertilizer, even in a given agro climatic zone and on a given crop, let alone among zones in a given country or sub region of Africa (Adanikin, 2008).

It is strongly believed that this study will bring about the adoption pattern of fertilizer technology. It will also correct the attitude of the farmers towards the adoption of the fertilizer technology. This is due to the fact that a problem known is half solved; therefore, once those factors are identified it will be easier to work on them. The ultimate significance of this study will be that of improvement in crop productivity (Yanggen, 1998).

\subsection{Perception of farmers on Adoption of new farm technology}

According to [24] the perception of farmers has an important role in diffusion of information about different farm technology. According to the view of these authors, in Africa, the result of different investigation outcome is vast and its dissemination has had a huge influence, particularly in developing countries for the decades. This impact is noticeable in the adoption of innovation by farmers with the goal of changing agricultural production (Aphunu and Otoikhian, 2007). However, the perception of farmers towards training could affect their decision on the acceptance of agricultural innovation. The significance of this investigation was to guess whether the attitude of farmers to training on selected improved agricultural technologies can significantly affect adoption of the technologies [16].

Agricultural development deduces a change from outdated systems of production to modern systems of production that comprise modern technological constituents, such as new diversities, traditional practices, commercial fertilizers and pesticides as well as new crops and modern farming systems.

However, a common feature of these strategies according to Poole (1994) is that government runs agricultural extension services dedicated to increase small holder productivity by encouraging the adoption of new scientific farming practices through educational procedures. The agricultural extension service functions from the background trust that improved agricultural productivity depends mainly upon the recognition of improved cultural and technological change at the rural farm level and that peasant farmers can achieve higher farm yields only if they adopt recommended scientific farming techniques in place of their traditional practices [2].

\section{Conclusions}

The key objective of this paper was to review a hypothetical background that conceptualizes Farmers' Training Centers (FTC) in Ethiopia. In Ethiopia, where community agricultural extension remains dominant and pluralism in service provision is fair developing; reinforcing community agricultural extension has received due strategy attention. Thousands of farmer training centers (FTCs) have been established by government with considerable contributions from rural communities.

There are several factors for ineffective implementation of farmers' training center. Some of the problem occurred due to Social constraint such as Low community participation, Drop out ,Expectation of benefit ,Lack of educated farmers and Lack of demonstration area .And the other problem is Institutional constraint Lack of commitment, Lack of teaching material, Lack of transportation, Lack of guideline and curriculum modules.

Even though huge numbers of FTC found in the country the agricultural productivity is still low and the role of farmers training center is ineffective and in some areas nonfunctional due to above listed problem. In some areas where farmers training center is well organized and equipped there is effective and important for generation and improving income of farmers as well as serve as key instrument in adoption of new farm technology. 
As a conclusion, this review shows that factors challenging effectiveness of FTC as well as an important in adoption of new farm technological and also improving living condition of farmers through increasing agricultural productivity and recommending when reviewing the importance of Farmers training center to researcher and policy makers.

\section{Recommendation}

The study has revealed various importance's of farmers training center in adoption of new farm technology in Ethiopia. Based on the major findings of the study, the following are some recommendations forwarded for practical intervention and policy implications despite decentralized skeleton of farmers training center (FTC).

* For sustainable agricultural development, the implementation of different modern farm technology is important to improving agricultural productivity, however the technical know-how and formal and informal education is important to apply this farm technology.

* The FTC works activities should be led by technical experts aiming to benefit the needy smallholder farmers than for political consumption. There is mismatch between the problems of agricultural production and available but "restricted" technologies and services to the farmers. Therefore, it is highly recommended that dissemination and promotion of agricultural technologies should be preceded by proper assessment of the needs and suitability to environment, cultural and economic situation with full participation of clients along with recommended packages.

* Even though number of Farmers training centers are found in Ethiopia majority of them did not give the targeted service. In many areas of the country the farmers training center serve as storage and the service of the center is low when it compared to the cost incurred for construction of FTC.

* Farmers' training Center is important in technology transfer, providing demonstration skills to transfer technologies in most part of the country. Also it is important in providing technical updates especially skill training and empowering rural productive forces, through FTC based on the needs of and using existing opportunities is wise in adoption of new farm technology.

* Even though, farmers' training center is important in improving living condition of farmers through improving agricultural productivity and in adoption of new farm technology in order to increase productivity, few research have been done on importance and challenging factors for implementation of farmers training center. Therefore, it is highly recommended that farmers training center important not only improving the income but also in adoption of new farm technology, due to this fact the researcher, policy maker and other responsible take into account proactive involvement Farmers' training center.

\section{Reference}

[1]Adanikin (2008). Adanikin,F.FAnalysis of factors determining adoption of pattern of fertilizerTechnology among small scale farmers in Akure South local government area”. Unpublished B.Tech Thesis, LAUTECH, Ogbomoso. Pp 1-49.

[2]Addis. (1991). The Role of Farmer Training Centers in Rural Development with a Special Reference to Ethiopia.

[3]Adesina(2001). Farmers' perceptions and adoption of new agricultural technology: evidence from analysis in Burkina Faso and Guinea, West Africa Farmers' perceptions andadoption of new agricultural technology: evidence from analysis in Burkina Faso and Guinea, West Afr .

[4]Adesina and Baidu . (1995). Farmers' Perception and Adoption of New Agricultural Technology: Evidence from analysis in BurkinaFaso and Guinea" west Africa Agricultural Economics, 13: 1-19.

[5]Alemayehu. (2008). Farmers' perceptions on the effectiveness of cooperatives indisseminating agricultural technologies. An M.Sc thesis presented to the School of Graduate Studies of Sokoine University, Morogoro, Tanzania.

[6]Ames. (1989). Human Capital, Agricultural Development and the African Food crisis. An Agricultural Administration and Extension.

[7]Aphunu and Otoikhian. (2007). Farmers' perception of the effectiveness of extension agents of Delta State Agricultural Development Programme (DADP). Nigeria.

[8]Aynalem. (2006). Technical Efficiency in Maize Production: A Case of Smallholder Farmers in Mecha District'. Ethiopia.

[9]Behailu. (2009).Determinants of Adoption Decision of Subsistence Farmer For Improved Soil Conservation Technologies: The Case Inbsea Sarmeder, Eastern Gojjam, Amhara Region. Ethiopia.

[10]Bekele and Pillai (2011). Training needs of members in cooperative dairy marketing in Ethiopia.

[11]Benin, Samuel, Ephraim Nkonya and Edward . (2012). Impact of the National Agricultural Advisory Services (Naads) program of Uganda: Considering Different Levels of Likely Contamination with the Treatment. American Journal of Agricultural Economics 94: 386-92.

[12]Berhanu, Hoekstra and Tegegne. (2006). Commercialization of Ethiopian agriculture: extension service from input supplier to knowledge broker and facilitator. IPMS of Ethiopian farmers' project working paper 1. ILRI, 
Nairobi.

[13]Bernor, Daniel and Baxter. (1984). Training and Visit Extension: The World Bank,Washington. Dc.

[14]Clark and Richard . (1987). Human Resource Development: Key to Extension Survival. Journal of Extension, $25,25-26$.

[15]Cramb. (2003 ). "Processes Affecting the Successful Adoption of New Technologies by Smallholders". In: B.Hacker, (ed). Working with Farmers: The Key to the Adoption of Forage Technologies, pp: 11-22. ACIARProceedings No. 95. Canberra: Australian Centre.

[16]Cunguara and Darnhofer. (2011). Assessing the impact of improved agricultural technologies on. Mozambique.

[17]Davis (2012). Impact of Farmer Field Schools on Agricultural Productivity and Poverty in East Africa. World Development 40: 402-13.

[18]Degnet and Belay . (2001). Factors influencing adoption of high yielding maize varieties in south western Ethiopia: An application of logit. Quart. International Journal of Agriculture. 40(2):149-167.

[19]EBA. (2005). Ethiopia Beekeeping Association annual report”. Proceedings.

[20]Enamul and Saedah. (2009). The role of agriculture education and training on agriculture economics and national development of Bangladesh.

[21]Erbaugh. Kibwika and Donnermeyer. (2007). Assessing extension agent knowledge and training needs to improve IPM dissemination in Uganda. J. Int. Agric. Extens.Educ., 14: 59-70.

[22]Esman and Milton(1980)Para Professional in Rural Development. New York: Ithaca.

[23]Fanos (2015) stimulatingthe uses of farmers training centers in Oromia. Ethiopia.

[24]FAO(2005). Statistical yearbook, FAOSAT.

[25]Feder and Zilberman( 1985 )Technical report on Adoption of Agricultural Innovation in.

[26]Fisseha. (2009). Problems And Prospects Of Farmers Training Centers:The Case Of Ada'a Woreda, East Shewa, Oromia Region. Haramaya ,Ethiopia.

[27]Kathleen \& Gale. (2009). Training for Rural Development:Agricultural and Enterprise Skills for Women Smallholders.

[28]Krishna P. Paudel Teeka Bhattarai,Yuba Raj Subedi . (2016). An Analysis of the Agricultural Development Strategy of Nepal (ADS 2015-2035). Nepal: Bagdol, Lalitpur.

[29]Lukuyu ,Place , Franzel \& Kiptot. (2012). Disseminating Improved Practices: Are Volunteer Farmer Trainers Effective? Nairobi, Kenya: Taylor \& Francis.

[30]Malede and Degsew. (2013). Perception of Farmers Towards the Use of Modern Beehives Technology in Amhara Region, Ethiopia. European Journal of Biological Sciences 5 (1): 01-08.

[31]Mahmud, Menale and Gunnar . (2009). Risk Implications of Farm Technology Adoption in the Ethiopian Highlands.

[32]Marshall. (1920 )Principles of Economics,( 8th ed.). New York, Macmillan.

[33]Mayank. (2012). Farmer's Attitude towards Adoption of Recommended Technology to Increase Productivity under Dry Land Area.

[34]MEDaC. (1999). Survey of Ethiopian Economy: Review of Post Reform Development (1992/93-1997/98). Addis Ababa, Ethiopia.

[35]Millennium Challenge Corporation. (2012). Impact Evaluation of the Farmer Training and Development Activity in Honduras Millennium Challenge Corporation Contract MCC-10-0133-CON-20 TO01. Washington.

[36]MoA (2002 ). ATVET Program of Agricultural Sector: MoA, Addis Ababa.

[37]MoARD. (2007). Livestock Development Master Plan Study.-Apiculture. Addis Ababa, Ethiopia,.

[38]MOARD (2009a). Ministry of Agriculture and Rural Development. DAs and FTC data at . Ethiopia.

[39]MoARD. (2009b). Overall number of extension agents data graduated from ATVET colleges. Unpublished, ATVET program coordination office, Agricultural Extension Directorate. MoARD, Addis Ababa.

[40]Tigist , Kavitha , Haimanot and Mohammed . (2017). Constraints and Challenges in Implementing Agricultural Extension Practices. The Case of North Gondar in Amhara Region, Ethiopia. Gondar,Ethiopia.

[41]Muluken and Maria . (2017). Impact of Farmers' Training Centres on Household Income: Evidence from Propensity ScoreMatching in Eastern Ethiopia. Ethiopia.

[42]Mwangi Kimenyi, Temesgen . Deressa, Jessica Pugliese. (2014). Participant Perception Of The Effectiveness Of The Rivers Songhai Initiative In The Niger Delta. Washington,Dc.

[43]Nigatu. (2010). Farmer training centres and IPMS programme in Ethiopia. Ethiopia.

[44]Njine. (2014). The Role of Agriculture Training Centers in Promoting Sustainable Rural Development in Kenya. Nairobi,Kenya.

[45]Nuru. (2007). Atlas of pollen grains of major honeybee flora of Ethiopia. Holeta Bee Research Centre.Commercial Printing Enterprise. Addis Ababa, Ethiopia. Pp 152.

[46]Parminter,(1997). Importance of farmers belief and attitude to the development and adopion of new farm technology. Hamilton. 
[47]Rogers and Svenning. (1969). Modernization among peasants. Rinchart and Winston . INC, New York.

[48]Rogers1988). Teaching Adults. Philadelphia, Open University Press. Philadelfia.

[49]Roling. (1988). Extension Science Information Systems in Agricultural Development. .

[50]Samson. ( 2007). Communication patterns among extension personnel and. Morogoro.

[51]Samuel. (2011). Returns to spending on agricultural extension: the case of the National Agricultural Advisory Services (NAADS) program of Uganda. Agricultural Economics 42: 249-67.

[52]Schultz. (1981). Investing in People-The economics of Population Quality. Berkley,.

[53]Sharma and Gupta. (2011). Enhancing the adoption of farm technology.

[54]Spicer. (1986). Human problems in technological change. In Peter E.Hildebrand Globalization. In Adult Education and Development, Institute for International Cooperation, Bonn.

[56]Swanson, Bentz and Safranko. (1997). Improving Agricultural Extension:a Reference manual, FAO. Rome.

[57]Tassew. (2009). The Impact of Agricultural Extension and Roads on Poverty and Consumption Growth in Fifteen Ethiopian Villages.American Journal of Agricultural Economics 91: 1007-21.

[58]Terrefe. (1992). Farmers' Training Programs with Special Emphasis on Residential Farmers Training centers in Ethiopia.

[59]Tesfaye , Ermias and Dirk . (2010). Status and Capacity of Farmer Training Centers (FTCs) Improving Productivity and Market Success (IPMS) Pilot Learning . Addis Ababa,Ethiopia.

[60]Tesfaye and Sehai(2011). Status and Capacity of Farmer Training CentersFTCs) in the Improving Productivity and Market Success (IPMS) Pilot Learning Woredas (PLWs). Addis Ababa:International Livestock Research Institute (ILRI).

[61]Tigist ,Kavitha, Nachimuthu, Haimanot and Mohammed. (2017). Constraints and Challenges in Implementing Agricultural Extension Practices. The Case of North Gondar in Amhara Region, Ethiopia . Gonder,Ethiopia.

[62]Todo, Yasuyuki and Ryo(2013). iImpact of Farmer Field Schools on Agricultural Income And Skills: Evidence From An Aid-Funded Project In Rural Ethiopia. Journal of International Development 25: 362-81. Ethiopia.

[63]Truong and Yamada(2002). Factors affecting farmers' adoption of technologies in farming system: A case study in OMon district, Can Tho province Mekong Delta.

[64]Tsion Ranjan and Teklu (2010). Farmers training effectiveness in terms of changes in knowledge and attitude: The case of Holeta, Melkassaand Debre zeit Agricultural Research Centres, Ethiopia.

[65]William,McBride and Daberkow (2003). Information and the Adoption of Precision Farming Technologies. Gorgea.

[66]Wuletaw (2014). Effectiveness of Modular Training at Farmers' Training Center: Evidence from Fogera District, South Gondar Zone, Ethiopia. Addis Ababa,Ethiopia.

[67]Yanggen (1998). Incentives for Fertilizer Use Saharan Africa: A review of empirical evidence on fertilize yield profitability International Development Working Paper no. 70 Michigan State.

[68]Waddington,Birte and Anderson (2010). The Impact of Agricultural Extension Services. 3ie Synthetic Reviews-SR009 Protocol January.

[69]Zewdie,Gemeda,Abule and Amenti (2015). Livestock and irrigation value chains for Ethiopian Smallholders. Ethiopia. 